\title{
Long-Term Improvements Observed in Tralokinumab-Treated Patients with Moderate-to-Severe Atopic Dermatitis: an ECZTEND Interim Analysis
}

Andrew Blauvelt, Jean-Philippe Lacour, ${ }^{2}$ Darryl Toth, ${ }^{3}$ Vivian Laquer, ${ }_{1}^{4}$ Stefan Beissert, ${ }_{1}^{5}$ Andreas Wollenberg, ${ }_{1}^{6}$ Pedro Herranz, ${ }_{1}^{7}$ Andrew Pink ${ }^{8}$ Ketty Peris, ${ }^{9}$ Stine Fangel, ${ }_{1}^{10}$ Hidehisa Saeki ${ }^{11}$

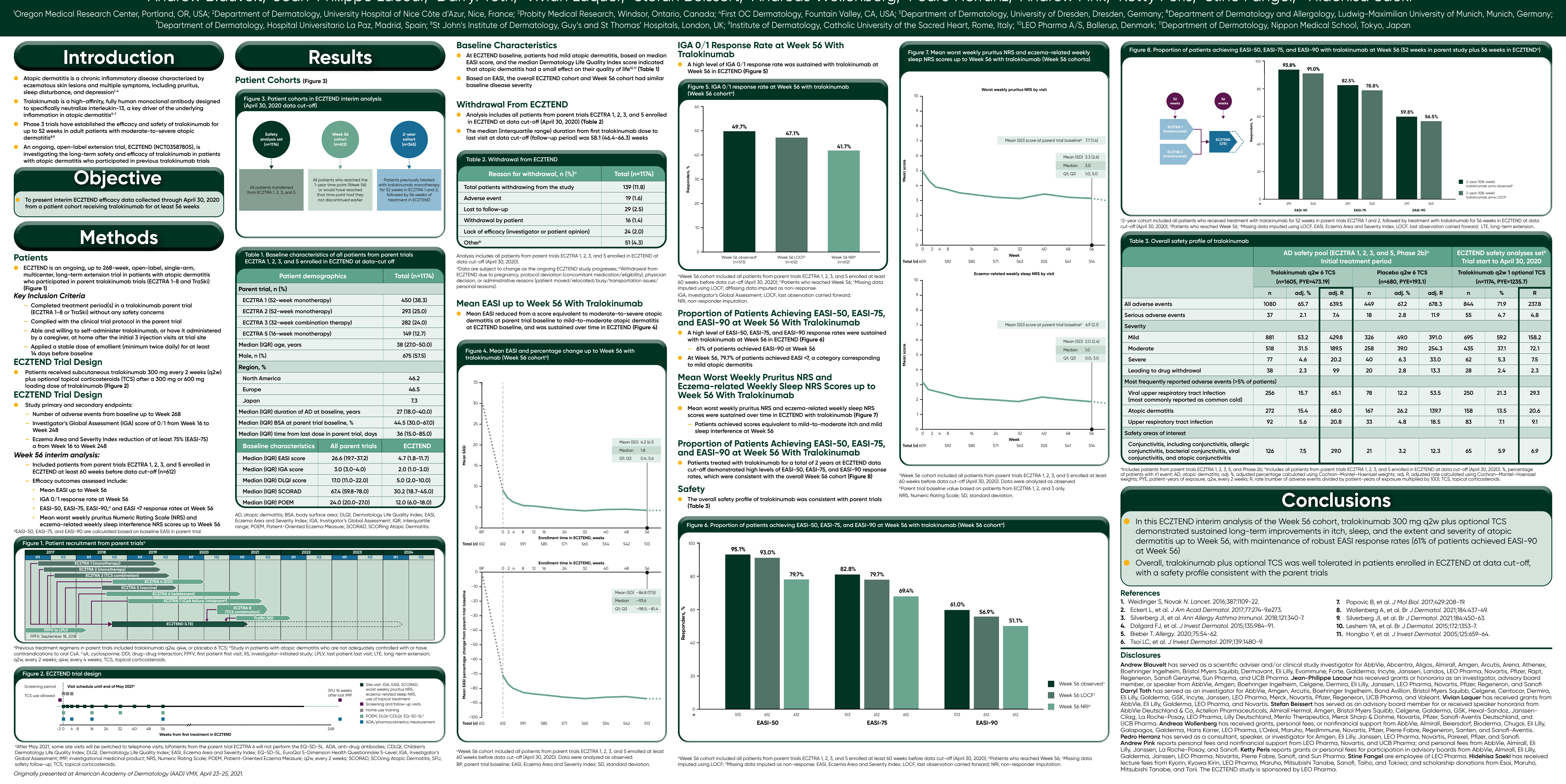

